\title{
Potassium aspartate inhibits SH-SY5Y cell damage and apoptosis induced by ouabain and $\mathrm{H}_{2} \mathrm{O}_{2}$
}

\author{
XUEFEI SUN ${ }^{1}$, DONGYU MIN ${ }^{2}$, YAN WANG ${ }^{1}$ and LIYING HAO ${ }^{1}$ \\ ${ }^{1}$ Department of Pharmaceutical Toxicology, School of Pharmaceutical Science, China Medical University, Shenyang, \\ Liaoning 110001; ${ }^{2}$ The Experimental Center of Traditional Chinese Medicine, \\ The Affiliated Hospital of Liaoning University of Traditional Chinese Medicine, Shenyang, Liaoning 110032, P.R. China
}

Received June 23, 2014; Accepted March 18, 2015

DOI: $10.3892 / \mathrm{mmr} .2015 .3741$

\begin{abstract}
The present study aimed to investigate the effects of L-aspartic acid potassium salt (potassium aspartate, $\mathrm{K}$-asp) on SH-SY5Y cells treated with ouabain and $\mathrm{H}_{2} \mathrm{O}_{2}$. An 3-(4,5-dimethylthiazol-2-yl)-2,5-diphenyltetrazolium bromide (MTT) assay was performed to investigate the effects of K-asp on SH-SY5Y cell death induced by ouabain. Nissl staining was used to demonstrate the morphological changes of the SH-SY5Y cells. Light microscopy and 4',6-diamidino-2-phenylindole (DAPI) staining were performed to visualize apoptosis in SH-SY5Y cells incubated with ouabain for 6 , 24 and $48 \mathrm{~h}$. Transmission electron microscopy was used to observe the effect of K-asp on ultrastructural changes of the SH-SY5Y cells following incubation with ouabain for 24 and $48 \mathrm{~h}$. An annexin V-fluorescein isothiocyanate/propidium binding assay and flow cytometry were performed successively to investigate how $\mathrm{K}$-asp affected the $\mathrm{H}_{2} \mathrm{O}_{2}$-induced cell apoptosis. The MTT assay demonstrated that K-asp attenuated the cytotoxicity of the SH-SY5Y cells following treatment with ouabain, in a dose-dependent manner. The cell survival rates following $48 \mathrm{~h}$ incubation in the $\mathrm{K}$-asp $(15 \mathrm{mM})$ and $\mathrm{K}$-asp (25 $\mathrm{mM}$ ) groups were higher compared with the $\mathrm{KCl}$ and MK801 groups. Nissl staining demonstrated that the severity of cell injury in the $\mathrm{KCl}$ and $\mathrm{K}$-asp $(25 \mathrm{mM})$ groups were alleviated. In the DAPI staining and transmission electron microscopy analyses, $\mathrm{KCl}$ and $\mathrm{K}$-asp $(25 \mathrm{mM})$ reduced the rate of ouabain-induced apoptosis. Flow cytometry revealed that $\mathrm{K}$-asp (25 mM) reduced $\mathrm{H}_{2} \mathrm{O}_{2}$-induced apoptosis. These results demonstrated that $\mathrm{K}$-asp $(25 \mathrm{mM})$ inhibited the ouabain and $\mathrm{H}_{2} \mathrm{O}_{2}$-induced SH-SY5Y cell damage and apoptosis, possibly by supplementing levels of intracellular $\mathrm{K}^{+}$.
\end{abstract}

Correspondence to: Dr Liying Hao, Department of Pharmaceutical Toxicology, School of Pharmaceutical Science, China Medical University, 92 Beier Road, Shenyang, Liaoning 110001, P.R. China E-mail: lyhao@mail.cmu.edu.cn

Key words: potassium aspartate, $\mathrm{KCl}$, ouabain, $\mathrm{H}_{2} \mathrm{O}_{2}$, apoptosis

\section{Introduction}

The potassium ion $\left(\mathrm{K}^{+}\right)$is an important ion, which is involved in the metabolism of sugar and protein in a variety of cell types, and maintains the balance between the $\mathrm{pH}$ and osmolarity of cells. It is essential in the formation of resting potential, neuromuscular excitability and the maintenance of normal myocardial diastolic movement coordination (1). Hypokalemia is a common disease in which abnormal concentrations of $\mathrm{K}^{+}$in the blood cause severe pathological changes, including muscle weakness, intestinal paralysis, sinus tachycardia, ventricular fibrillation and other arrhythmias (2). Hypokalemia is caused by various factors, including insufficient food, vomiting, severe diarrhea, kidney disease, digitalism and long-term use of glucocorticoids (3). The major treatment for hypokalemia is $\mathrm{K}^{+}$supplementation. L-aspartic acid potassium salt (K-asp) is commonly used in the clinical treatment of hypokalemia $(4,5)$, in which L-aspartic acid is used as the carrier to transport $\mathrm{K}^{+}$into the cells (6). However, the protective effect of $\mathrm{K}$-asp in nerve cells surrounded by a low potassium environment remains to be elucidated.

Several neurodegenerative diseases, including Alzheimer's disease, Parkinson's disease, amyotrophic lateral sclerosis, ischemia and excitotoxicity are associated with oxidative injury (7). Previous findings have indicated that oxidative damage may be associated with reactive oxygen species (ROS) and manifested by cell lysis, oxidative bursting or excessive quantities of free transition metals $(8,9) \cdot \mathrm{H}_{2} \mathrm{O}_{2}$ is one type of ROS, which has been used as an important reagent to establish an in vitro model of oxidative stress injury (10). Ouabain is an $\mathrm{Na}^{+}$and $\mathrm{K}^{+}$-adenosine triphosphate (ATP)ase inhibitor, which can induce concentration-dependent neuronal cell death. Neuronal cell swelling is followed by cell shrinkage, which is accompanied by an increase in intracellular $\mathrm{Na}^{+}$and decrease in $\mathrm{K}^{+}(11)$. In the present study, the anti-apoptotic effect of $\mathrm{K}$-asp was investigated in ouabain-treated and $\mathrm{H}_{2} \mathrm{O}_{2}$-treated human SH-SY5Y cells.

\section{Materials and methods}

Cells and drugs. Human SH-SY5Y cells were obtained from American Type Culture Collection (Rockville, MD, USA) and were cultured in Dulbecco's modified Eagle's medium 
(Invitrogen Life Technologies, Carlsbad, CA, USA), supplemented with $10 \%$ fetal bovine serum(Gibco Life Technologies, Carlsbad, CA, USA) and $100 \mathrm{U} / \mathrm{ml}$ penicillin/streptomycin (Sigma-Aldrich, St. Louis, MO, USA). The cells were incubated in a humidified incubator at $37^{\circ} \mathrm{C}$ with $5 \% \mathrm{CO}_{2}$, and the medium was replaced every 2 days. Ouabain (Sigma-Aldrich, St. Louis, MO, USA), $\mathrm{H}_{2} \mathrm{O}_{2}$ (Sigma-Aldrich), $25 \mathrm{mM} \mathrm{KCl}$, $2 \mu \mathrm{M}$ MK801 (Sigma-Aldrich) and 15, 25, 50 or $75 \mathrm{mM} \mathrm{K}$-asp (Liaoning Union Pharmaceutical Co., Ltd., Liaoning, China) were dissolved in distilled water. $\mathrm{KCl}, \mathrm{MK} 801$ and $\mathrm{K}$-asp were added $4 \mathrm{~h}$ prior to treatment with either ouabain or $\mathrm{H}_{2} \mathrm{O}_{2}$. The present study was approved by the ethics committee of China Medical University (Shenyang, China).

Analysis of cell death using a 3-(4,5-dimethylthiazol-2-yl)-2,5-diphenyltetrazolium bromide (MTT) assay. The human SH-SY5Y cells were plated into 96-well plates at a concentration of $5 \times 10^{3}$ cells/well and were incubated with $\mathrm{KCl}$ (25 mM), MK801 (2 $\mu \mathrm{M})$ or K-asp (15 mM, $25 \mathrm{mM}, 50 \mathrm{mM}$ or $75 \mathrm{mM}$ ), at $37^{\circ} \mathrm{C}$ for $4 \mathrm{~h}$, prior to the addition of ouabain $(100 \mu \mathrm{M})$. Following treatment, the cells were incubated for 24 and $48 \mathrm{~h}$. The cells were treated with MTT $(0.5 \mathrm{mg} / \mathrm{ml} /$ well $)$ for $4 \mathrm{~h}$, prior to the MTT being replaced with $150 \mu \mathrm{l}$ dimethyl sulfoxide (DMSO) and the absorption was determined at $570 \mathrm{~nm}$ using a spectrophotometric plate reader (680; Bio-Rad Laboratories, Inc., Hercules, CA, USA).

Nissl staining. The human SH-SY5Y cells $\left(5 \times 10^{4}\right)$ were plated into 24-well plates and incubated, as described above. Following incubation with $100 \mu \mathrm{M}$ ouabain for 6,24 or $48 \mathrm{~h}$, the cells were fixed with $4 \%$ paraformaldehyde (Sinopharm Chemical Reagent Co., Ltd., Shanghai, China) and subsequently incubated in Nissl solution (1\%) at room temperature for $12 \mathrm{~min}$. The stained cells were observed under a light microscope (CK X41; Olympus, Tokyo, Japan).

Analysis of apoptosis using 4',6-diamidino-2-phenylindole (DAPI) staining. The human SH-SY5Y cells $\left(5 \times 10^{4}\right)$ were plated onto a cover slip and incubated as described above. Following incubation with $100 \mu \mathrm{M}$ ouabain for 24 or $48 \mathrm{~h}$, the cells were fixed with $4 \%$ paraformaldehyde and incubated in DAPI solution $(100 \mathrm{ng} / \mathrm{ml})$ for $1 \mathrm{~min}$ in the dark. The stained cells were observed under a fluorescence microscope (BX61/DP71; Olympus).

Transmission electron microscopy. The cells were incubated as described above. Following incubation with $100 \mu \mathrm{M}$ ouabain for 24 and $48 \mathrm{~h}$, the cells were fixed using 4\% gluteraldehyde (Sinopharm Chemical Reagent Co., Ltd.) in $0.1 \mathrm{M}$ phosphate buffer ( $\mathrm{pH} 7.4$; Sinopharm Chemical Reagent Co., Ltd.), and postfixed with $1 \%$ osmioum tetroxide (Sinopharm Chemical Reagent Co., Ltd.) in $0.1 \mathrm{M}$ cacodylate (Sinopharm Chemical Reagent Co., Ltd.) buffer for $1 \mathrm{~h}$ at $4^{\circ} \mathrm{C}$. The cells $\left(5 \times 10^{4}\right)$ were subsequently dehydrated using ethanol (50, 70 and 90\%), infiltrated using acetone and epoxy resin (Structure Probe, Inc., West Chester, PA, USA), and finally embedded in capsules (Agar Scientific, Essex, UK). Polymerization was performed at $60^{\circ} \mathrm{C}$ for $48 \mathrm{~h}$. Thin sections were cut with a diamond knife on an ultramicrotome and mounted onto slot grids (Ted Pella, Inc., Redding, CA,
USA). The unstained sections were observed under a Hitachi H-600 transmission electron microscope (Hitachi, Tokyo, Japan).

Flow cytometry. The cells $\left(1 \times 10^{6}\right)$ were incubated, as described above. Following incubation with $100 \mu \mathrm{M} \mathrm{H}_{2} \mathrm{O}_{2}$ for $48 \mathrm{~h}$, the cells were collected into tubes and washed twice with $10 \mathrm{ml}$ phosphate-buffered saline (PBS; Sinopharm Chemical Reagent Co., Ltd.). The cells ( $1 \times 10^{6}$ cells/sample) were stained with annexin V-fluorescein isothiocyanate (FITC)/propidium iodide (PI; BD Biosciences, San Jose, CA, USA), according to the manufacturer's instructions (BD Biosciences, San Jose, CA, USA), and subsequently analyzed on a fluorescence-activated cell sorting instrument (FACSAsia; Becton Dickinson, Franklin Lakes, NJ, USA). The PI- and annexin V-negative cells (lower left quadrant) were considered to be normal, PI-negative and annexin V-positive cells (lower right quadrant) were considered early apoptotic cells, PI- and annexin V-positive cells (upper right quadrant) were considered late apoptotic cells, and the PI-positive and annexin V-negative cells (upper left quadrant) were considered mechanically injured. All experiments were performed in triplicate and representative figures produced.

Statistical analysis. The results were analyzed using SPSS 13.0 software (SPSS, Inc., Chicago, IL, USA). The data are expressed as the mean \pm standard deviation. Two groups of mean values were compared using Student's t-test. $\mathrm{P}<0.05$ was considered to indicate a statistically significant difference.

\section{Results}

$K$-asp attenuates the cytotoxicity of ouabain on SH-SY5Y cells in a dose-dependent manner. To investigate the effect of K-asp on ouabain-induced cell death, an MTT assay was performed. The viability of the SH-SY5Y cells exposed to ouabain for $24 \mathrm{~h}$ was $65.89 \pm 3.41 \%$ of that in the control group. The viabilities of the cells treated with $\mathrm{KCl}, \mathrm{MK} 801$, $\mathrm{K}$-asp (25 mM) and K-asp (50 mM) were 93.21 $\pm 3.67(\mathrm{P}<0.01)$, $84.49 \pm 1.89(\mathrm{P}<0.01), 91.32 \pm 1.75(\mathrm{P}<0.01)$ and $74.19 \pm 0.82 \%$ $(\mathrm{P}<0.05)$, respectively (Fig. 1A). The cells exposed to ouabain for $48 \mathrm{~h}$ was $88.37 \pm 9.08 \%$ of that of the control group. The viabilities of the cells treated with K-asp (15 and $25 \mathrm{mM})$ were 101.20 $\pm 19.07(\mathrm{P}<0.05)$ and $101.40 \pm 12.54 \%(\mathrm{P}<0.01)$, respectively (Fig. 1B). The data suggested that K-asp attenuated the ouabain-induced cytotoxicity of the SH-SY5Y cells in a dose-dependent manner.

$K$-asp decreases the severity of ouabain-induced necrosis in the SH-SY5Y cells, in a dose-dependent manner. To observe the morphological changes of the SH-SY5Y cells, Nissl staining was performed. Following incubation with ouabain for 6, 24 and $48 \mathrm{~h}$, the control group exhibited few injured cells, and the visual field was predominantly clear and intact cells without cell necrosis. However, a significant proportion of the cells in the ouabain group were damaged, exhibiting extensive degenerative changes, including sparse cell arrangements, loss of integrity, a shrunken cytoplasm and swollen cell bodies (Fig. 2). The cells of the $48 \mathrm{~h}$ incubation group exhibited more severe injury compared with those in the 6 and $24 \mathrm{~h}$ incubation groups. By contrast, the severity 
A

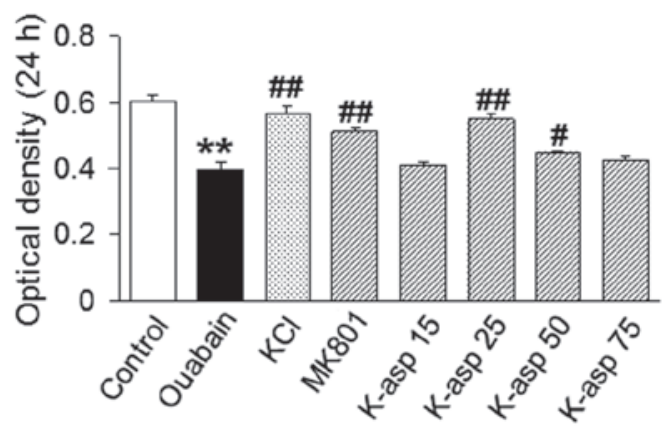

C

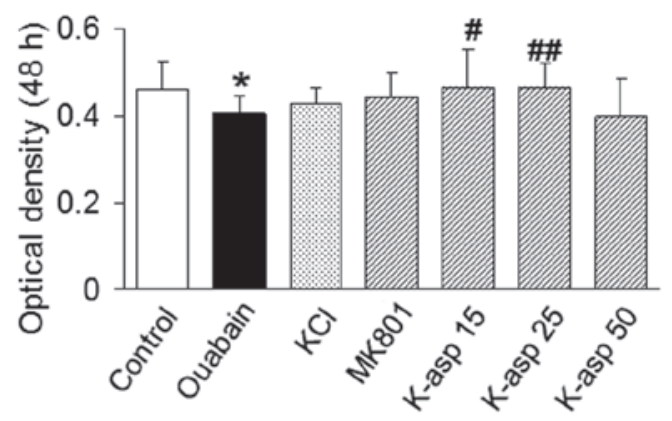

B

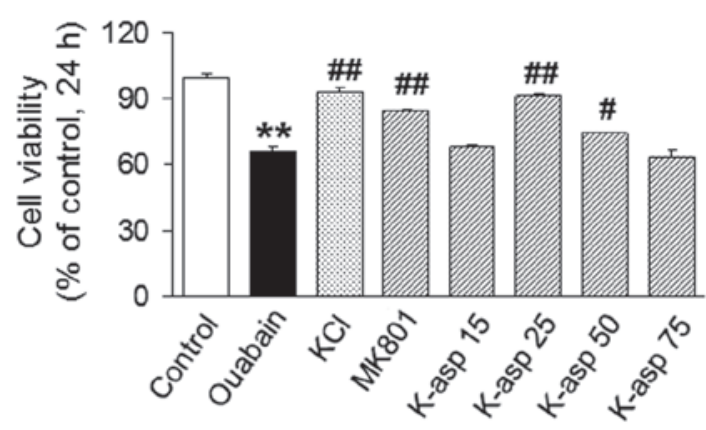

D

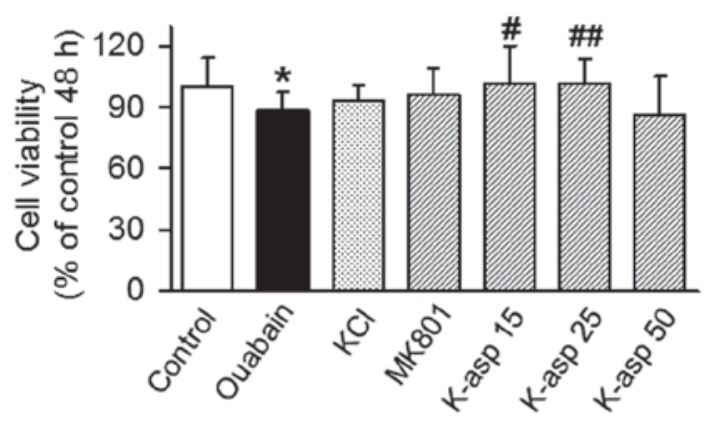

Figure 1. Effect of K-asp on SH-SY5Y cell death induced by ouabain. (A) Optical density of SH-SY5Y cells treated with $100 \mu \mathrm{M}$ ouabain for $24 \mathrm{~h}$. (B) Viability of SH-SY5Y cells treated with $100 \mu \mathrm{M}$ ouabain for $24 \mathrm{~h}$, expressed as the percentage of the control. (C) Optical density of SH-SY5Y cells treated with $100 \mu \mathrm{M}$ ouabain for $48 \mathrm{~h}$. (D) Viability of SH-SY5Y cells treated with $100 \mu \mathrm{M}$ ouabain for $48 \mathrm{~h}$, expressed as the percentage of the control. KCl ( $25 \mathrm{mM}$ ), MK801 $(2 \mu \mathrm{M})$ or K-asp $(15 \mathrm{mM}, 25 \mathrm{mM}, 50 \mathrm{mM}$ or $75 \mathrm{mM})$ were added $4 \mathrm{~h}$ prior to treatment with ouabain. Independent experiments were repeated three times. The data are expressed as the mean \pm standard error of the mean. $\mathrm{P}<0.05$ and ${ }^{* *} \mathrm{P}<0.01$, compared with the control; ${ }^{\#} \mathrm{P}<0.05$ and ${ }^{\# \#} \mathrm{P}<0.01$, compared with the ouabain-treated cells. K-asp, potassium aspartate.

of cell necrosis in the $\mathrm{KCl}$, MK801, K-asp (15 mM) and K-asp $(25 \mathrm{mM})$ groups was alleviated, whereas cell necrosis in K-asp $(50 \mathrm{mM})$ and $\mathrm{K}$-asp $(75 \mathrm{mM})$ groups was not. These results suggested that K-asp alleviated the severity of ouabain-induced necrosis in the SH-SY5Y cells, in a dose-dependent manner.

K-asp ameliorates ouabain-induced apoptosis of SH-SY5Y cells, and $25 \mathrm{mM} K$-asp is the most effective concentration. To examine the apoptotic response of the SH-SY5Y cells incubated with ouabain for 6,24 or $48 \mathrm{~h}$, light microscopy and DAPI staining were performed. In the control group, the cell structures were clear, synapses were complete and large quantities of the stained nuclei were uniform and oval in shape. In the ouabain-treated group, the cell structures were unclear and the number of viable cells were reduced, with a large quantity of cell fragments. The nuclei were unevenly stained, their shape and size were irregular, and their number was significantly reduced. The number of cells in the ouabain-treated group, following incubation for 24 and $48 \mathrm{~h}$, was significantly reduced compared with the control group. In the $\mathrm{KCl}$ group, light microscopy revealed that the cell structures were clear and few cells were round, and the results of the DAPI staining demonstrated that the number of the cells was increased. In the MK801 group, light microscopy revealed that the cell structures were clear and only a few cell fragments were observed, with the DAPI staining demonstrating few cell shape abnormalities. In the K-asp (25 mM) group, light microscopy revealed higher numbers of cells and fewer cell fragments, compared with the $\mathrm{KCl}$, MK801, K-asp (15 mM) and $\mathrm{K}$-asp $(50 \mathrm{mM})$ groups (Fig. 3). These data demonstrated that K-asp ameliorated the ouabain-induced apoptosis of the SH-SY5Y cells, with K-asp ( $25 \mathrm{mM}$ ) being the most effective.

K-asp (25 mM) reduces cellular ultrastructure changes, induced by ouabain. To determine the effect of K-asp on ultrastructure changes of the SH-SY5Y cells following incubation with ouabain for 24 and $48 \mathrm{~h}$, the cells were visualized using transmission electron microscopy. In the control group, the cell membrane and nuclear membrane were intact, and the structures of the mitochondria and endoplasmic reticulum were clear. The ouabain group exhibited incomplete cell membranes, cell shrinkage, nuclear cleavage fragments, sparse necrotic cell chromatin, irregular granular distribution, cell swelling and damage to the organelle structures. By contrast, the $\mathrm{KCl}$ group and $\mathrm{K}$-asp $(25 \mathrm{mM})$ group exhibited nuclear chromatin condensation, crescent- or ring-shaped nuclear membrane bodies and clear organelle structures (Fig. 4). These data suggested that $\mathrm{KCl}$ and $\mathrm{K}$-asp $(25 \mathrm{mM})$ alleviated the cellular ultrastructure changes, which were induced following treatment with ouabain.

K-asp (25 mM) ameliorates the apoptosis of SH-SY5Y cells induced by $\mathrm{H}_{2} \mathrm{O}_{2}$. To determine how K-asp affected $\mathrm{H}_{2} \mathrm{O}_{2}$-induced cell apoptosis, an annexin V-FITC/PI binding 


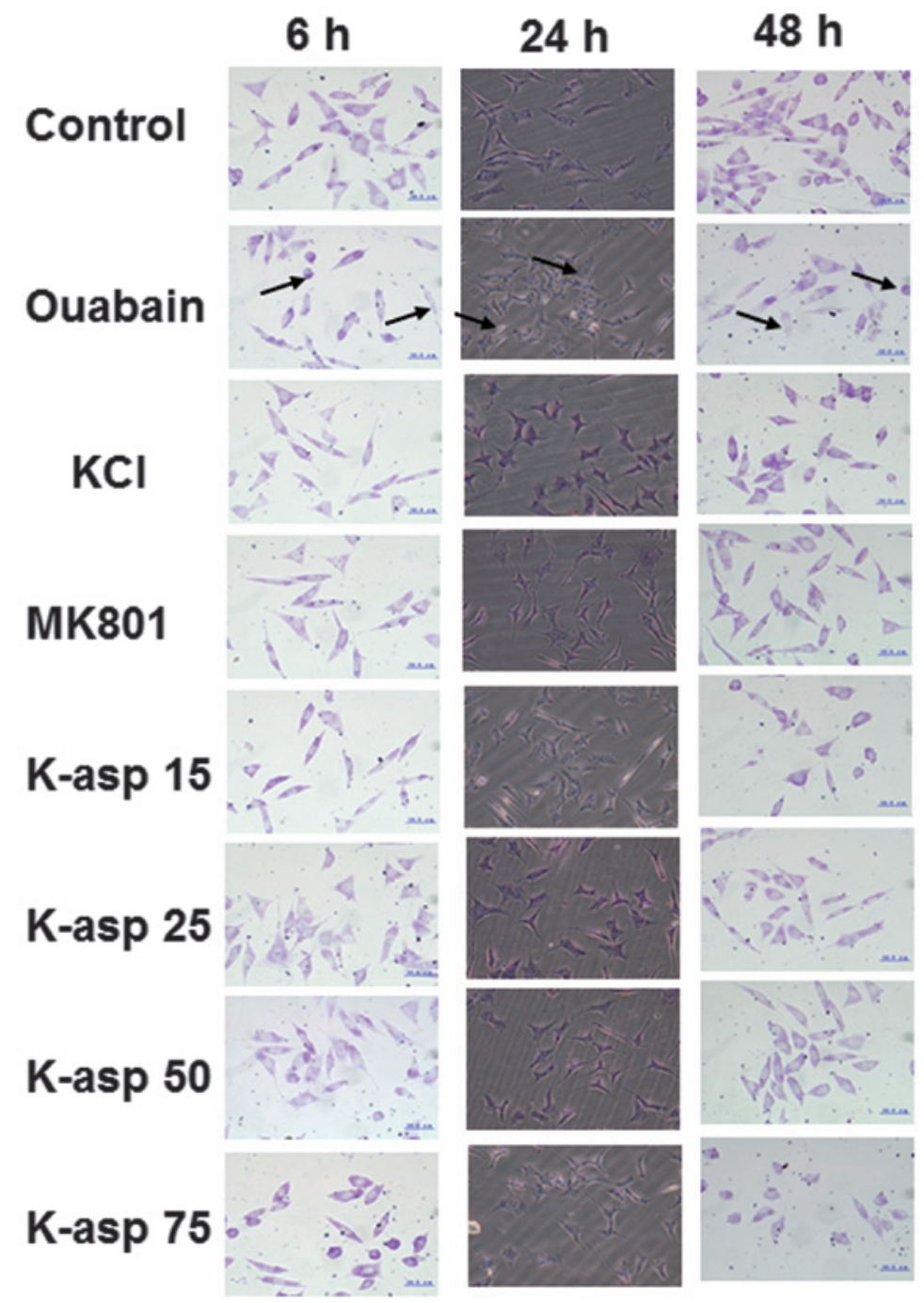

Figure 2. Effect of K-asp on the cytotoxicity of SH-SY5Y cells following incubation with ouabain for 6, 24 and 48 h. Images were captured (magnification, x200) following Nissl staining. KCl (25 mM), MK801 $(2 \mu \mathrm{M})$, K-asp $15(15 \mathrm{mM})$, K-asp $25(25 \mathrm{mM})$, K-asp $50(50 \mathrm{mM})$ or K-asp 75 (75 mM) were added $4 \mathrm{~h}$ prior to treatment with ouabain $(100 \mu \mathrm{M})$. The stained Nissl bodies are demonstrated in the images of SH-SY5Y cells. Nissl bodies are indicators for nerve cell functions. Arrows indicate the damaged cells (scale bar=50 $\mu \mathrm{m}$ ). K-asp, potassium aspartate.

assay and flow cytometry were performed to detect cell apoptosis. In the double parameter dot plots (Fig.5), an increased number of cells in the LR area were indicative of early apoptotic cells and those in the UR area were indicative late apoptotic cells (Fig. 5A). In the control group, the early apoptotic population of the SH-SY5Y cells was $1.38 \pm 0.50 \%$ and the late apoptotic population was $3.69 \pm 0.98 \%$, combining to a total apoptotic population $5.07 \pm 0.87 \%$. In the $\mathrm{H}_{2} \mathrm{O}_{2}$ group, the early apoptotic population of cells was $10.29 \pm 3.96 \%$ and the late apoptotic population was $10.09 \pm 0.85 \%$, combining to a total apoptotic population $20.38 \pm 3.89 \%$. The total number of apoptotic population of the cells in $\mathrm{H}_{2} \mathrm{O}_{2}$ group was significantly higher than that in the control group $(\mathrm{P}<0.001)$. In the K-asp $(25 \mathrm{mM})$ group, the early apoptotic population of cells was $0.77 \pm 0.45 \%$ and the late apoptotic population was $4.89 \pm 1.56 \%$, combining to a total apoptotic population of $5.66 \pm 1.98 \%$. The total apoptotic population of the cells in K-asp $(25 \mathrm{mM})$ group was significantly decreased, compared with the $\mathrm{H}_{2} \mathrm{O}_{2}$ group $(\mathrm{P}<0.001$; Fig. 5E). These data demonstrated that $\mathrm{K}$-asp $(25 \mathrm{mM})$ ameliorated the apoptotic response of the- $\mathrm{H}_{2} \mathrm{O}_{2}$-induced SH-SY5Y cells.

\section{Discussion}

Ouabain is a $\mathrm{Na}^{+}-\mathrm{K}^{+}$-ATP enzyme inhibitor, which increases the levels of $\mathrm{Na}^{+}$and $\mathrm{Ca}^{2+}$ and decreases the levels of $\mathrm{K}^{+}$ under intracellular conditions (11). In the early period of ouabain treatment (2-6 h), SH-SY5Y cells swell and the cell volume decreases gradually, resulting in cell apoptosis and necrosis (11). Previous studies have demonstrated that intracellular $\mathrm{K}^{+}$concentrations are reduced to $80 \%$ in neurons treated with ouabain for $12 \mathrm{~h}$ (12-14). The present study demonstrated that, following treatment with ouabain for $24 \mathrm{~h}$, the number of cells was significantly decreased and the cell survival rate was significantly increased in the $\mathrm{KCl}, \mathrm{MK} 801$ and K-asp $(25 \mathrm{mM})$ groups. No difference in cell survival rate was observed between the $\mathrm{KCl}$ and $\mathrm{K}$-asp $(25 \mathrm{mM})$ groups, and the cell survival rates in these two groups were higher compared with that in the MK801 group. The cell survival rates following incubation for $48 \mathrm{~h}$ in the K-asp $(15 \mathrm{mM})$ and $\mathrm{K}$-asp $(25 \mathrm{mM})$ groups were higher compared with the $\mathrm{KCl}$ and MK801 groups. These results indicated that $\mathrm{KCl}$ had a short-term protective effect against cellular damage caused by 


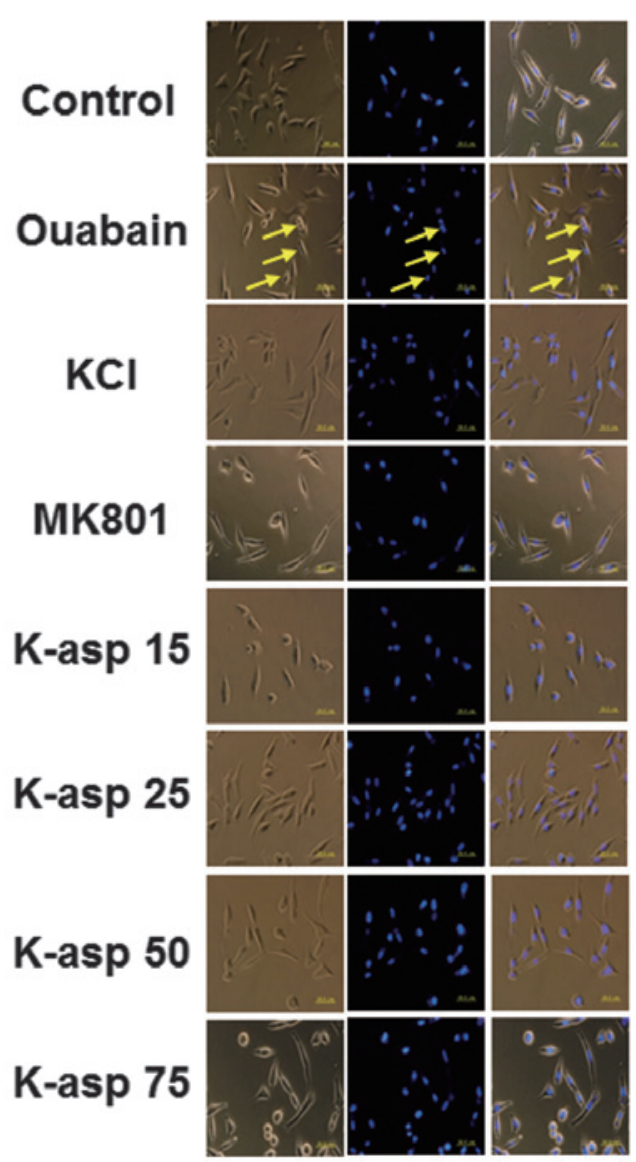

B
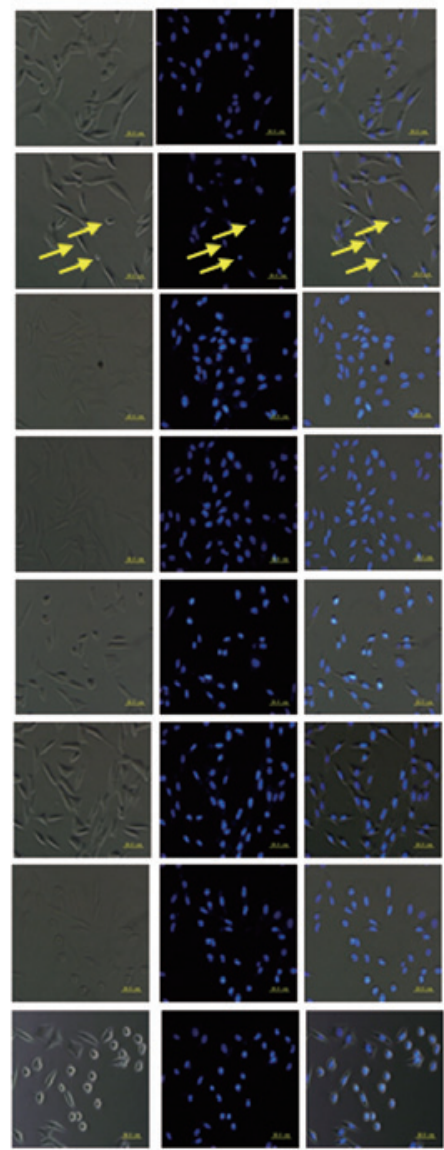

C

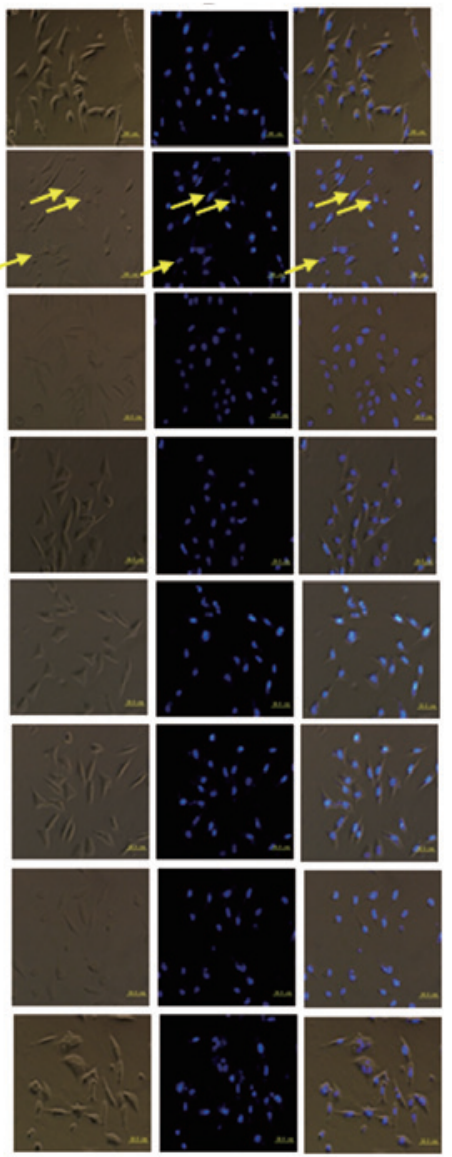

Figure 3. Effect of K-asp on the apoptosis of SH-SY5Y cells following incubation with ouabain for (A) 6, (B) 24 and (C) 48 h. The left column of images were captured under light microscopy (magnification, x200) with no staining, the middle column of images were captured following DAPI staining, and the right column of images represent a merge of the respective left and middle columns of images. $\mathrm{KCl}(25 \mathrm{mM}), \mathrm{MK} 801(2 \mu \mathrm{M}), \mathrm{K}$-asp 15 (15 mM), K-asp 25 (25 mM), $\mathrm{K}$-asp $50(50 \mathrm{mM})$ or K-asp $75(75 \mathrm{mM})$ were added $4 \mathrm{~h}$ prior to treatment of the cells with ouabain $(100 \mu \mathrm{M})$. Arrows indicate damaged cells (scale bar=0 $\mu \mathrm{m})$. K-asp, potassium aspartate.

Control

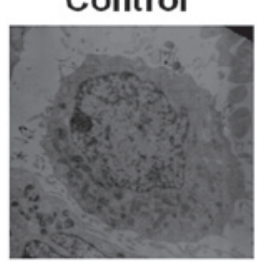

$24 \mathrm{~h}$

$48 \mathrm{~h}$

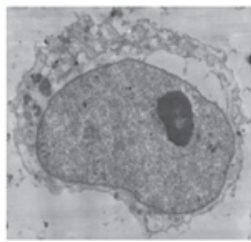

Ouabain
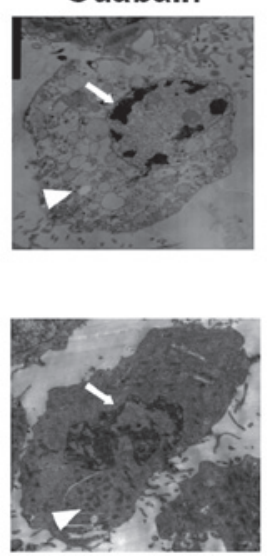

$\mathrm{KCl}$
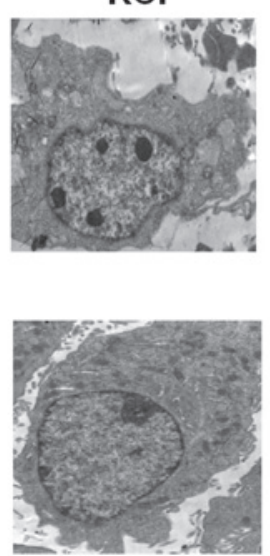

\section{K-asp 25}
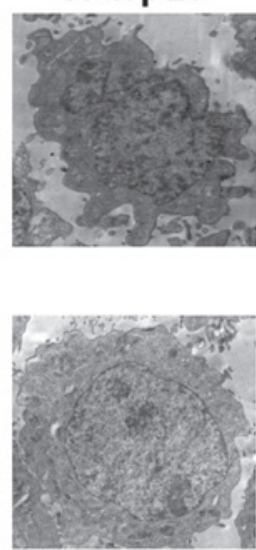

Figure 4. Effect of K-asp on the apoptosis of SH-SY5Y cells following incubation with ouabain for 24 and $48 \mathrm{~h}$. Images were captured under a transmission electron microscope. $\mathrm{KCl}(25 \mathrm{mM})$ or K-asp $25(25 \mathrm{mM})$ were added $4 \mathrm{~h}$ prior to treatment of the cells with ouabain $(100 \mu \mathrm{M})$. Arrows indicate nuclear cleavage fragments; triangles indicate organelle structural damages. K-asp, potassium aspartate.

low potassium, however, K-asp exhibited a longer duration of protective effects compared with $\mathrm{KCl}$.

Nissl bodies indicate nerve cell functions (12). The results of the Nissl staining in the present study demonstrated that the cells in the $\mathrm{KCl}$, MK801 and $\mathrm{K}$-asp (25 mM) groups exhibited darker staining, compared with those in the ouabain group, with the number of cells being increased. This observation indicated that $\mathrm{K}$-asp and $\mathrm{KCl}$ protected against ouabain-induced cell damage.

As a well-established model of in vitro SH-SY5Y cell oxidative stress, $\mathrm{H}_{2} \mathrm{O}_{2}$ can readily pass through the cell 
A

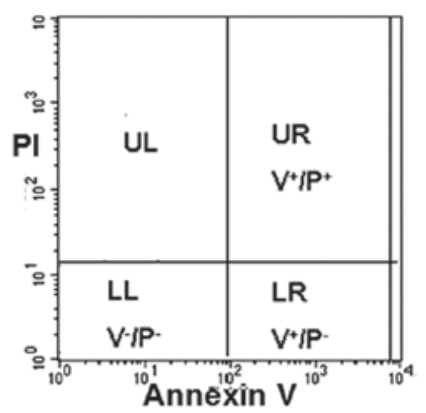

D

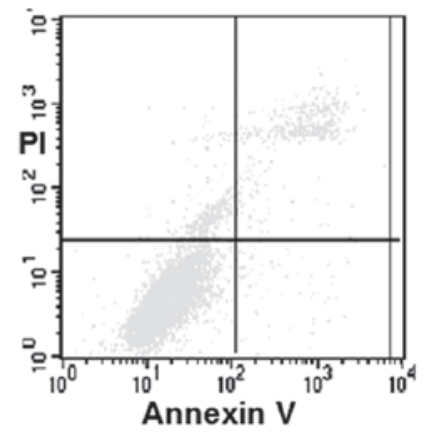

B
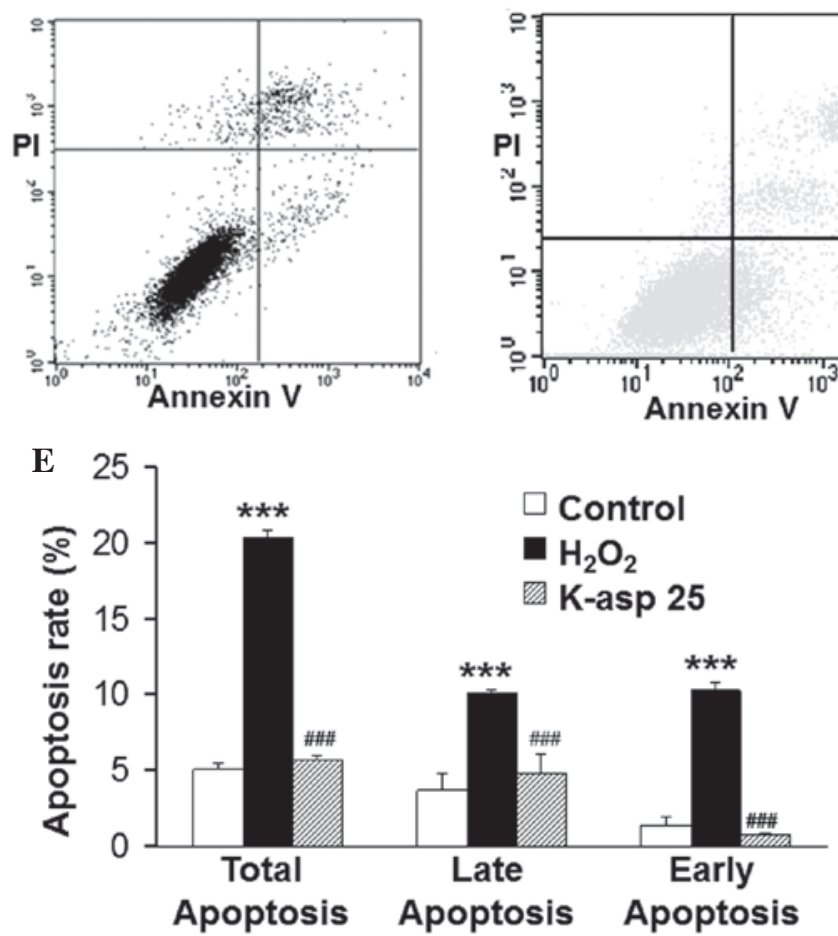

Figure 5. Effect of K-asp on the apoptosis of SH-SY5Y cells following incubation with $\mathrm{H}_{2} \mathrm{O}_{2}$ for 48 h. Apoptosis was determined using an annexin-V fluorescein isothiocyanate/propidium iodide binding assay and flow cytometry. $\mathrm{K}$-asp $(25 \mathrm{mM})$ was added $4 \mathrm{~h}$ prior to treatment of the cells with $\mathrm{H}_{2} \mathrm{O}_{2}(100 \mu \mathrm{M})$. (A) Normal cells $\left(\mathrm{V}^{-} / \mathrm{PI}^{-}\right)$were indicated in the LL quadrant of the dot plot, early apoptotic cells $\left(\mathrm{V}^{+} / \mathrm{P}^{+}\right)$were indicated in the $\mathrm{UR}$ dot quadrant and late apoptotic cells $\left(\mathrm{V}^{+} / \mathrm{P}^{-}\right)$were indicated in the LR quadrant. (B) Dot plot of cells in the control group. (C) Dot plot of cells in the $\mathrm{H}_{2} \mathrm{O}_{2}$ group. (D) Dot plot of cells in the K-asp group. (E) Histograms of the percentages of apoptosis, based on the accumulation of annexin-V FITC positive cells in UR and LR quadrants. The data are expressed as the mean \pm standard error of the mean $\left({ }^{* * *} \mathrm{P}<0.001\right.$, compared with the control group; ${ }^{\# \#} \mathrm{P}<0.001$, compared with the $\mathrm{H}_{2} \mathrm{O}_{2}$ group). $\mathrm{K}$-asp, potassium aspartate; V, annexin-V fluorescein isothiocyanate; P, propidium iodide, ${ }^{+}$, positive; ', negative; UL, upper left; UR, upper right; LL, lower left; LR, lower right.

membrane and cause cell damage, resulting in the disturbance of ion homeostasis $(15,16) . \mathrm{H}_{2} \mathrm{O}_{2}$ inhibits $\mathrm{Na}^{+}-\mathrm{K}^{+}$-pump activity and decreases intracellular levels of $\mathrm{K}^{+}$. A previous study demonstrated that apoptotic cell dehydration was caused by the loss of $\mathrm{K}^{+}(17)$. In cancerous tissues, fewer $\mathrm{K}_{\mathrm{V}} 1.1$ and $\mathrm{K}_{\mathrm{V}} 1.3$ potassium channels are expressed and the cell apoptosis is abnormal, indicating that potassium channels may contribute to apoptosis (18). Another previous study demonstrated cerebellar granule neuron apoptosis following the transfer of cells from different extracellular potassium concentrations (19). In the present study, K-asp $(25 \mathrm{mM})$ protected the SH-SY5Y cells from the induction of apoptosis following incubation with $\mathrm{H}_{2} \mathrm{O}_{2} 48 \mathrm{~h}$. The total apoptotic population of the cells in the $\mathrm{H}_{2} \mathrm{O}_{2}$ group was significantly increased compared with the control group, however, this effect was suppressed following treatment with K-asp $(25 \mathrm{mM})$. Subsequent analysis revealed that the protective effect of K-asp $(25 \mathrm{mM})$ was persistent in the early and late periods of apoptosis. These results demonstrated that $\mathrm{K}$-asp (25 mM) significantly reduced the apoptotic rate of the cells, however, excessively high $\mathrm{K}^{+}$concentrations $(\geq 50 \mathrm{mM}$ ) resulted in apoptosis. These results were consistent with those reported in previous studies $(20,21)$.

It has been reported that ouabain inhibits the reduction in Bcl-2 and the increases the phosphorylation of the pro-apoptotic factor, p53, in SH-SY5Y cells (13). Ouabain, a $\mathrm{Na}^{+}-\mathrm{K}^{+}$-ATP enzyme inhibitor, increases levels of intracellular
$\mathrm{Na}^{+}$and promotes $\mathrm{Na}^{+}-\mathrm{Ca}^{2+}$ exchange, which causes intracellular calcium overload and activates caspase-3 and endogenous nucleases, leading to apoptosis and irreversible damage (11). In the present study, analysis using DAPI staining and transmission electron microscopy revealed that $\mathrm{KCl}$ and $\mathrm{K}$-asp (25 $\mathrm{mM}$ ) reduced the level of apoptosis induced by ouabain. The annexin V-FITC/PI binding assay indicated that K-asp (25 mM) also reduced apoptosis, which was induced by $\mathrm{H}_{2} \mathrm{O}_{2}$. In the present study, MK801, a NMDA receptor antagonist, reduced ouabain-induced cell damage caused.

Decreased intracellular ions lead to decreased intracellular osmotic crystals and the outflow of water molecules, causing a reduction in cell volume (19). This is partly consistent with the results of the present study. K-asp, a novel energy type potassium agent, has a high affinity towards cells. Aspartic acid contributes to the citric acid cycle to provide ATP for the body and to assist in $\mathrm{Na}^{+}-\mathrm{K}^{+}$-ATP enzyme recovery (22). In the present study, K-asp (15 $\mathrm{mM}$ and $25 \mathrm{mM}$ ) had a better protective effect compared with $\mathrm{KCl}$, whereas the cells in the $\mathrm{K}$-asp (75 mM) group exhibited severe damage, caused by the high concentration of $\mathrm{K}^{+}(23,24)$.

In conclusion, the present study demonstrated that K-asp (25 mM) had protective effects on the SH-SY5Y cells, with superior effects compared with $\mathrm{KCl}$, following incubation for $48 \mathrm{~h}$. This suggested that K-asp supplemented the levels of intracellular $\mathrm{K}^{+}$and inhibited the apoptosis of the SH-SY5Y cells. 


\section{References}

1. Abe $\mathrm{K}$ and Saito $\mathrm{H}$ : Involvement of $\mathrm{Na}^{+}-\mathrm{K}^{+}$pump in L-glutamate clearance by cultured rat cortical astrocytes. Biol Pharm Bull 23 . $1051-1054,2000$.

2. Ueno Y, Ogino Y and Kinouchi T: Sodium, potassium. Nihon Rinsho 12: 250-256, 2004 (In Chinese).

3. Willard MD: Disorders of potassium homeostasis. Vet Clin North Am Small Anim Pract 19: 241-263, 1989.

4. Shiino A, Nishida Y, Yasuda H, Suzuki M, Matsuda M and Inubushi T: Magnetic resonance spectroscopic determination of a neuronal and axonal marker in white matter predicts reversibility of deficits in secondary normal pressure hydrocephalus. J Neurol Neurosurg Psychiatry 75: 1141-1148, 2004.

5. Suleiman MS, Dihmis WC, Caputo M, Angelini GD and Bryan AJ: Changes in myocardial concentration of glutamate and aspartate during coronary artery surgery. Am J Physiol 272: H1063-H1069, 1997.

6. Saunders EC, Ng WW, Chambers JM, et al: Isotopomer profiling of Leishmania mexicana promastigotes reveals important roles for succinate fermentation and aspartate uptake in tricarboxylic acid cycle (TCA) anaplerosis, glutamate synthesis and growth J Biol Chem 286: 27706-27717, 2011.

7. Olanow CW and Tatton WG: Etiology and pathogenesis of Parkinson's disease. Annu Rev Neurosci 22: 123-144, 1999.

8. Bellavite P: The superoxide-forming enzymatic system of phagocytes. Free Radic Biol Med 4: 225-261, 1988.

9. Halliwell B and Gutteridge JM: Lipid peroxidation in brain homogenates: the role of iron and hydroxyl radicals. J Neurochem 69: 1330-1331, 1997.

10. Gardner AM, Xu FH, Fady C, Jacoby FJ, Duffey DC, Tu Y and Lichtenstein A: Apoptotic vs. nonapoptotic cytotoxicity induced by hydrogen peroxide. Free Radic Biol Med 22: 73-83, 1997.

11. Xiao AY, Wei L, Xia S, Rothman S and Yu SP: Ionic mechanism of ouabain induced concurrent apoptosis and necrosis in individual cultured cortical neurons. Neuroscience 22: 1350-1362, 2002.

12. Huang X, Moir RD, Tanzi RE, Bush AI and Rogers JT: Redox-active metals, oxidative stress and Alzheimer's disease pathology. Ann N Y Acad Sci 1012: 153-163, 2004.

13. Kulikov A, Eva A, Kirch U, Boldyrev A and Scheiner-Bobis G Ouabain activates signaling pathways associated with cell death in human neuroblastoma. Biochim Biophys Acta 1768: 1691-1702, 2007.
14. Yu SP, Yeh C, Strasser U, Tian M and Choi DW: NMDA receptor mediated $\mathrm{K}+$ efflux and neuronal apoptosis. Science 284: 336-339, 1999.

15. Wang XQ, Xiao AY, Sheline C, et al: Apoptotic insults impair $\mathrm{Na}^{+}-\mathrm{K}^{+}$-ATPase activity as a mechanism of neuronal death mediated by concurrent ATP deficiency and oxidant stress. J Cell Sci 116: 2099-2110, 2003.

16. Xiao AY, Wang XQ, Yang A and Yu SP: Slight impairment of Na+-K+-ATPase synergistically aggravates ceramide- and beta-amyloid-induced apoptosis in cortical neurons. Brain Res 955: 253-259, 2002.

17. Yurinskaya VE, Rubashkin AA and Vereninov AA: Balance of unidirectional monovalent ion fluxes in cells undergoing apoptosis: why does $\mathrm{Na}+\mathrm{K}+$ pump suppression not cause cell swelling? J Physiol 589: 2197-2211, 2011.

18. Brevet M, Ahidouch A, Sevestre H, Merviel P, El Hiani Y, Robbe $\mathrm{M}$ and Ouadid-Ahidouch $\mathrm{H}$ : Expression of $\mathrm{K}+$ channels in normal and cancerous human breast. Histol Histopathol 23: 965-972, 2008

19. Hernández-Enríquez B, Arellano RO and Morán J: Role for ionic fluxes on cell death and apoptotic volume decrease in cultured cerebellar granule neurons. Neuroscience 167: 298-311, 2010.

20. Huang XP, Tan H, Chen BY and Deng CQ: Astragalus extract alleviates nerve injury after cerebral ischemia by improving energy metabolism and inhibiting apoptosis. Biol Pharm Bull 35: 449-454, 2012.

21. Wang M, Qiu J, Mi W, Wang F and Qu J: In vitro effect of altering potassium concentration in artificial endolymph on apoptosis and ultrastructure features of olfactory bulb neural precursor cells. Neurosci Lett 487: 383-388, 2011.

22. Jorgensen PL and Pedersen PA: Structure-function relationships of $\mathrm{Na}+\mathrm{K}+$, ATP, or $\mathrm{Mg} 2+$ binding and energy transduction in Na, K-ATPase. Biochim Biophys Acta 1505: 57-74, 2001.

23. Gugliotta T, De Luca G, Romano P, Rigano C, Scuteri A and Romano L: Effects of lead chloride on human erythrocyte membranes and on kinetic anion sulphate and glutathione concentrations. Cell Mol Biol Lett 17: 586-597, 2012.

24. Noguchi T, Kamiyama N and Kashiwayanagi M: Modulation of voltage-gated ion channels on SH-SY5Y neuroblastoma by non-ionic surfactant, Cremophor EL. Biol Pharm Bull 33: 2013-2017, 2010 